\title{
EDUKASI KESEHATAN REPRODUKSI MENGGUNAKAN MEDIA VIDEO MENINGKATKAN PENGETAHUAN REMAJA TENTANG MENSTRUASI PERTAMA
}

\author{
Siti Rusyanti ${ }^{1}$, Achadiyani ${ }^{2}$, Ieva Baniasih Akbar $^{3}$ \\ ${ }^{1}$ Poltekkes Kemenkes Banten \\ ${ }^{2}$ Fakultas Kedokteran Universitas Padjajaran Bandung \\ ${ }^{3}$ Fakultas Kedokteran Universitas Islam Bandung \\ Korespondensi : siti.rusyanti@poltekkesbanten.ac.id
}

\begin{abstract}
Adolescence is a period susceptible to various reproduction problems because of lack of knowledge regarding reproduction health. The result of study by UNICEF in Indonesia in 2015 showed that one of six teenage girls had to be absent from school for 1 day or more during menstruation. So far the material related to puberty was often given by lecturing including in Serang city, Banten, so they only used their hearing. The study aimed to compare the improvement of knowledge and attitude of teenagers after using video and lecturing regarding the menarche. The research method use Quasi Experiment with pretest-posttest control grup design. The sample size in this study was 35 teenagers in video group and 34 teenagers in lecturing. The sample technique was random permuted blocks and analysis using U MannWhitney test. The result of the study showed video could improve the knowledge ( $p$ value <0.001). Lecturing could improve the knowledge ( $p$ value <0.001). There was an improvement of knowledge of the teenagers in the video group but no higher than the teenagers in the lecturing group ( $p$ value $=0,185$ ). The conclusion of the study is that video improves the knowledge of teenagers in facing menarche.
\end{abstract}

Keywords: Menarche, video, lecturing, knowledge.

\begin{abstract}
ABSTRAK
Masa remaja adalah masa yang rentan terhadap berbagai masalah reproduksi karena kurangnya pengetahuan mengenai kesehatan reproduksi. Hasil studi UNICEF di Indonesia pada tahun 2015 menunjukkan bahwa satu dari enam gadis remaja harus absen dari sekolah selama 1 hari atau lebih selama menstruasi. Sejauh ini materi yang berkaitan dengan pubertas sering diberikan dengan metode ceramah termasuk di kota Serang, Banten, sehingga remaja hanya menggunakan indera pendengaran mereka. Media audiovisual melibatkan pendengaran dan penglihatan pada saat yang sama dalam suatu proses. Penelitian ini bertujuan untuk membandingkan peningkatan pengetahuan remaja setelah menggunakan video dan ceramah tentang menstruasi pertama. Metode penelitian menggunakan Quasi Experiment dengan desain kelompok kontrol pretestposttest. Ukuran sampel dalam penelitian ini adalah 35 remaja pada kelompok video dan 34 remaja pada kelompok ceramah. Teknik sampel adalah teknik random permuted blocks dan analisis menggunakan uji U Mann-Whitney. Hasil penelitian menunjukkan video dapat meningkatkan pengetahuan (nilai $\mathrm{p}<0,001$ ). Metode ceramah dapat meningkatkan pengetahuan (nilai $\mathrm{p}<0,001$ ). Terdapat peningkatan pengetahuan remaja pada kelompok video tetapi tidak lebih tinggi dari remaja pada kelompok ceramah (nilai $\mathrm{p}=0,185$ ). Simpulan dari penelitian ini adalah bahwa video meningkatkan pengetahuan remaja dalam menghadapi menstruasi pertama.
\end{abstract}

Kata Kunci: Menstruasi Pertama, Video, Ceramah, Pengetahuan. 


\section{PENDAHULUAN}

Informasi tentang menstruasi pertama harus diketahui oleh remaja putri sejak dini sehingga remaja dapat mendeteksi secara mandiri kondisi normal atau terjadi kelainan menstruasi, hal ini dilakukan agar stigma negatif yang berhubungan dengan menstruasi dapat dihilangkan. Informasi tentang menstruasi pertama selama ini diberikan di sekolah melalui UKS dan bimbingan konseling siswa oleh guru dengan metode ceramah, namun pada pelaksanaannya belum optimal karena keterbatasan tenaga kesehatan dan media edukasi. Edukasi dengan menggunakan metode ceramah kurang efektif dalam meningkatkan pengetahuan dan sikap remaja, oleh karena itu diperlukan edukasi menggunakan media yang lebih efektif untuk mempersiapkan remaja putri menghadapi menstruasi pertama. Media video merupakan media pembelajaran yang dapat menjadi alternatif keterbatasan di lapangan, saat ini belum ada kurikulum khusus membahas kesehatan reproduksi remaja sehingga belum adanya alokasi waktu yang disediakan, dengan menggunakan media video, dapat mengatasi keterbatasan waktu tersebut dan dapat mengatasi keterbatasan petugas kesehatan yang memberikan penyuluhan, remaja dapat mengakses informasi kesehatan reproduksi yang dibutuhkan. Pada era digital seperti sekarang ini, video akan mudah diakses oleh remaja. Media video dapat dilakukan pada siswa dengan kelas besar, kecil maupun perorangan. Untuk itu dibuat sebuah media video animasi tentang menstruasi pertama, yang dapat digunakan untuk menyampaikan edukasi dalam menghadapi menstruasi pertama. Penting dilakukan penelitian untuk menganalisis perbandingan peningkatan pengetahuan remaja setelah penggunaan media video dan metode ceramah tentang menstruasi pertama. Hal ini dianggap penting dan melatarbelakangi peneliti untuk melakukan penelitian tentang bagaimana pengaruh edukasi kesehatan reproduksi menggunakan media video terhadap pengetahuan remaja dalam menghadapi menstruasi pertama.

\section{METODE}

Desain penelitian menggunakan Quasi Experiment dengan pendekatan pretestposttest design with control group. Populasi target yaitu seluruh siswi SD sederajat yang berusia 10-11 tahun di wilayah kota Serang, populasi terjangkau yaitu seluruh siswi SD kelas 5 usia 10-11 tahun di SD Islam Tirtayasa Kota Serang dan SD Islam Al Azhar 10 kota Serang. Ukuran sampel penelitian ini adalah 35 remaja kelompok video dan 34 remaja kelompok ceramah. Teknik pengambilan sampel menggunakan 
teknik random permuted blocks. Ijin penelitian ini berasal dari Komisi Etik Penelitian Kesehatan Fakultas Kedokteran Universitas Padjadjaran dengan nomor Surat Persetujuan Etik: 63/UN6,KEP/EC/2018.

\section{HASIL}

Tabel 1 Karakteristik subjek penelitian

\begin{tabular}{cccc}
\hline \multirow{2}{*}{$\begin{array}{c}\text { Usia } \\
\text { tahun })\end{array}$} & $\begin{array}{c}\text { Kedia } \\
\text { video } \\
(\mathbf{n = 3 5})\end{array}$ & $\begin{array}{c}\text { Metode } \\
\text { ceramah } \\
(\mathbf{n}=\mathbf{3 4})\end{array}$ & $\mathbf{n = 6 9}$ \\
\hline 10 & $\begin{array}{c}21 \\
(60 \%)\end{array}$ & $17(50 \%)$ & 38 \\
& $\begin{array}{c}\text { Total } \\
11\end{array}$ & $17(50 \%$ & 31 \\
& $(40 \%)$ & & \\
\hline $\begin{array}{c}\text { Rata-rata } \\
\text { (SD) }\end{array}$ & $\begin{array}{c}10,4 \\
(0,5)\end{array}$ & $10,5(0,5)$ & 10,5 \\
& & & $(0,5)$ \\
\hline
\end{tabular}

Tabel 2 Uji Normalitas Data

\begin{tabular}{|c|c|c|}
\hline $\begin{array}{c}\text { Kelompok } \\
\text { Data }\end{array}$ & Nilai $p^{*}$ & Keterangan \\
\hline $\begin{array}{l}\text { Pre-kelompok } \\
\text { video } \\
\text { (pengetahuan) }\end{array}$ & 0,001 & $\begin{array}{c}\text { Tidak } \\
\text { Normal }\end{array}$ \\
\hline $\begin{array}{l}\text { Post-kelompok } \\
\text { video } \\
\text { (pengetahuan) }\end{array}$ & 0,000 & $\begin{array}{l}\text { Tidak } \\
\text { Normal }\end{array}$ \\
\hline $\begin{array}{l}\text { Pre-kelompok } \\
\text { ceramah } \\
\text { (pengetahuan) }\end{array}$ & 0,101 & Normal \\
\hline $\begin{array}{l}\text { Post-kelompok } \\
\text { ceramah } \\
\text { (pengetahuan) }\end{array}$ & 0,001 & $\begin{array}{c}\text { Tidak } \\
\text { Normal }\end{array}$ \\
\hline $\begin{array}{l}\text { \% naik } \\
\text { pengetahuan } \\
\text { (video) }\end{array}$ & 0,000 & $\begin{array}{c}\text { Tidak } \\
\text { Normal }\end{array}$ \\
\hline $\begin{array}{l}\text { \% naik } \\
\text { pengetahuan } \\
\text { (ceramah) }\end{array}$ & 0,174 & Normal \\
\hline
\end{tabular}

Tabel 3 Pengetahuan pada Kelompok Media Video dan Metode Ceramah Sebelum Dilakukan Intervensi (Data Pre)

\begin{tabular}{lccc}
\hline \multicolumn{1}{c}{ Variabel } & \multicolumn{2}{c}{ Kelompok } & \\
\cline { 2 - 3 } & $\begin{array}{c}\text { Media } \\
\text { video } \\
(\mathbf{n = 3 5})\end{array}$ & $\begin{array}{c}\text { Metode } \\
\text { ceramah } \\
(\mathbf{n}=\mathbf{3 4})\end{array}$ & $\begin{array}{c}\text { Nilai } \\
\mathbf{p}^{*}\end{array}$ \\
\hline Pengetahuan & & & 0,115 \\
Rata-rata & 80,8 & 76,3 & \\
(SD) & $(14,2)$ & $(13,9)$ & \\
Median & 86,7 & 73,3 & \\
Rentang & $33,3-100$ & $46,7-100$ & \\
\hline
\end{tabular}

Tabel 4 Pengetahuan pada Kelompok Media Video dan Metode Ceramah Setelah Dilakukan Intervensi (Data Post)

\begin{tabular}{cccc}
\hline $\begin{array}{c}\text { Variabel } \\
\text { (Skala 100) }\end{array}$ & \multicolumn{2}{c}{ Kelompok } & Media \\
\cline { 2 - 3 } & $\begin{array}{c}\text { Metode } \\
(\mathbf{n}=35)\end{array}$ & $\begin{array}{c}\text { Nilai } \\
\text { ceramah } \\
(\mathbf{n = 3 4 )}\end{array}$ & $\mathbf{p}^{*}$ \\
\hline Pengetahuan & & & 0,132 \\
Rata- & 91,8 & $89,6(89)$ & \\
rata (SD) & $(10,1)$ & & \\
Median & 93,3 & 90 & \\
Rentang & $66,7-$ & $60-100$ & \\
& 100 & & \\
\hline
\end{tabular}

Tabel 5 Perbandingan Peningkatan Pengetahuan pada Kelompok Media Video dan Metode Ceramah

\begin{tabular}{cccc}
\hline $\begin{array}{c}\text { Variabel } \\
\text { (Skala 100) }\end{array}$ & \multicolumn{2}{c}{ Kelompok } & \\
\cline { 2 - 3 } & $\begin{array}{c}\text { Media } \\
\text { video } \\
(\mathbf{n = 3 5})\end{array}$ & $\begin{array}{c}\text { Metode } \\
\text { ceramah } \\
(\mathbf{n = 3 4 )}\end{array}$ & $\begin{array}{c}\text { Nilai } \\
\mathbf{p}\end{array}$ \\
\hline Pengetahuan & $\mathrm{p}<0,001$ & $\mathrm{p}<0,001$ & \\
Perbandin \\
gan pre vs \\
post (Uji \\
$\begin{array}{l}\text { Mann- } \\
\text { Whitney) }\end{array}$ & & & \\
\hline $\begin{array}{c}\text { \% naik } \\
\text { (median) }\end{array}$ & $15,4 \%$ & $18,2 \%$ & $0,185^{*}$ \\
\hline *) Uji Mann-Whitney & & & \\
\hline
\end{tabular}

PEMBAHASAN

Remaja mengalami menarche pada usia 11 sampai 15 tahun. Periode ini akan 
mengubah perilaku dalam beberapa aspek seperti psikologi dan lainnya. (Hurlock,2011; Makmun,2012). Edukasi kesehatan reproduksi tentang persiapan menghadapi menstruasi pertama pada remaja dengan menggunakan media video merupakan salah satu cara penting dalam proses belajar.(Daryanto, 2010)

Hasil penelitian ini menunjukkan bahwa edukasi kesehatan reproduksi tentang persiapan menghadapi menstruasi pertama pada remaja dengan menggunakan media video dapat meningkatkan pengetahuan remaja dalam menghadapi menstruasi pertama. Hal ini sesuai dengan hasil penelitian Husaini dkk yang menunjukkan bahwa ada hubungan antara pemberian penyuluhan tentang HIV/AIDS dengan pengetahuan mahasiswa tentang HIV/AIDS. Mahasiswa yang mendapatkan penyuluhan tentang HIV/AIDS memiliki pengetahuan 4,206 kali lebih baik daripada mahasiswa yang tidak mendapatkan penyuluhan. (Husaini, et al., 2016). Pemberian penyuluhan kesehatan memengaruhi secara menguntungkan terhadap pengetahuan terkait dengan kesehatan individu. Penyuluhan dengan media audio visual dan konvensional dapat memengaruhi peningkatan pengetahuan.(Sinta, 2011; Wirawan, et al, 2014)

Edukasi kesehatan reproduksi tentang persiapan menghadapi menstruasi pertama pada remaja diberikan dalam bentuk pemberian informasi kepada remaja, hal ini dapat dilakukan dengan metode ceramah yang merupakan metode menerangkan materi pembelajaran secara lisan kepada peserta didik. Metode ini diterapkan pada kelompok peseta didik dalam jumlah yang besar. Melalui metode ceramah pendidik dapat mendorong munculnya inspirasi bagi peserta didik. Metode ini amat cocok untuk penyampaian bahan belajar yang berupa informasi.(Utama, 2017)

Hasil penelitian menunjukkan median skor pengetahuan sebelum penyuluhan dengan media video sebesar 86,7 dan sesudah penyuluhan sebesar 93,3 sedangkan dengan menggunakan metode ceramah sebelum penyuluhan sebesar 73,3 dan sesudah penyuluhan sebesar 90, secara statistik terdapat peningkatan skor pengetahuan yang bermakna pada kedua kelompok $(\mathrm{p}<0,001)$. Pada penelitian sebelumnya menunjukkan hasil yang sejalan bahwa intervensi berupa penyuluhan pada responden dengan media ceramah dan pemutaran video meningkatkan pengetahuan responden secara signifikan.(Yanti dan Raphaeli, 2012)

Pada tabel 5 hasil median skor peningkatan pengetahuan pada kelompok video sebesar 15,4\%, lebih rendah dari kelompok metode ceramah $18,2 \%$ dan nilai $\mathrm{p}$ sebesar 0,185 $\quad(\mathrm{p}>0,05) \quad$ sehingga dapat disimpulkan bahwa peningkatan pengetahuan 
menggunakan metode ceramah lebih tinggi dibandingkan dengan menggunakan media video. Hal ini sejalan dengan hasil penelitian sebelumnya bahwa perbandingan peningkatan pengetahuan WUS tentang Keluarga Berencana pada kelompok perlakuan ceramah dan kelompok perlakuan video menunjukkan tidak adanya perbedaan yang bermakna dengan nilai kemaknaan 0,071 ( $p>0,05)$.(Putri, et al., 2016). Hasil penelitian ini juga sesuai dengan hasil penelitian sebelumnya yang dilakukan oleh Wahyono yang menyatakan bahwa metode ceramah yang dilakukan pada pemberian informasi tentang bahaya merokok pada remaja memberikan dampak peningkatan pengetahuan pada remaja.(Wahyono dan Maharani, 2011) Hasil penelitian yang dilakukan oleh Lubis R, dkk tentang pengaruh tingkat pengetahuan dan sikap ibu terhadap penyakit kecacingan pada Balita menunjukkan bahwa sesudah responden diberikan intervensi penyuluhan dengan menggunakan media ceramah dan video, terdapat peningkatan pengetahuan sebesar $43 \%$, lebih rendah dari peningkatan sikap yang baik sebesar 52\%.(Lubis, et al., 2018)

\section{SIMPULAN}

Simpulan dalam penelitian ini adalah:

1. Media video meningkatkan pengetahuan remaja tentang menstruasi pertama
2. Metode ceramah meningkatkan pengetahuan remaja dalam menghadapi menstruasi pertama

3. Media video tidak lebih baik dibandingkan dengan metode ceramah dalam meningkatkan pengetahuan.

\section{DAFTAR RUJUKAN}

Hurlock EB. Psikologi Perkembangan Edisi ke-5. Yogyakarta; Erlangga: 2011.

Lubis R, Panggabean M, Yulfi H. Pengaruh Tingkat Pengetahuan dan Sikap Ibu terhadap Penyakit Kecacingan Pada Balita. Jurnal Kesehatan Lingkungan Indonesia. 2018;17(1):39-45 DOI 10.14710/jkli.17.1.39-45.

Makmun A. S. Psikologi Pendidikan. 2012. Bandung. PT Remaja Rosdakarya.

Putri D.M, Wahyudi F, Margawati A. Perbedaan Retensi Memori Pasca Penyuluhan Keluarga Berencana dengan Media Ceramah dan Video pada Wanita Usia Subur. Jurnal Kedokteran Diponegoro. 2016; 5 (4): 682-693.

Sinta. Promosi Kesehatan. Yogyakarta: Graha Ilmu;2011.

Utama, P.K.L. E-Learning Sebagai Evolusi Proses Pembelajaran di Era Masyarakat Informasi. Jurnal Penjaminan Mutu. 2017.

Wahyono B, Maharani C. Peningkatan Pengetahuan tentang Bahaya Merokok pada Siswa SLTPN Limbangan Kendal. 2011, 12 (1).

Wirawan, Susilo dkk. Penyuluhan dengan Media Audio Visual dan Konvensional terhadap Pengetahuan Ibu Anak Balita. Jurnal Kesehatan Masyarakat Universitas Negeri Semarang. 2014; Vol. 10 (1).

Yanti G.N, Raphaeli S. Perbedaan peningkatan pengetahuan antara metode ceramah dan pemutaran video kartun (Differenciation of knowledge increment between lecturing method). Dentika Dental Journal. 2012;17(1):1. 